\title{
Urban Rivers: A Landscape Ecological Perspective
} Jun Yue*

Shenzhen Urban Planning and Land Resource Research Center, 518034, P.R. China

\begin{abstract}
Urban rivers are important physical elements and important ecological corridors. They not only play important ecological roles but also supply bases of stability, comfort, and sustainability in urban development. Due to the complex interaction between inner and outer elements of urban river landscapes, it is necessary to use the theory of landscape ecology to analyze the pattern, function, context, fragmentation and temporal change of urban river landscapes with appropriate scale. It will support the management and sustainable development of urban rivers. The main purpose of this paper is to analyze the urban river landscapes from landscape ecological perspective. This paper firstly reviews the relevant studies in urban river landscapes, and then it carries out the research on the pattern of river corridors and river networks and the service functions. Next, it probes into the river landscape dynamic change at pattern and function aspects and the scale of relative study. Specially, because urban rivers are widely influenced by human activities, so this paper analyzes the disturbance of urban rivers further. This paper has proposed a basal framework for the research on urban rivers by the use of fundamental topics including pattern, function and dynamic change and so on in landscape ecology. It will play a directive role to understand urban rivers, resolve the water environment problems and to realize the sustainable development of urban river resources.
\end{abstract}

Keywords: Urban rivers; Landscape; Landscape Ecology; Pattern; Function; Change

\section{Introduction}

Urban rivers include rivers, or river segments, which originate or flow in urban regions, as well as canals or channels (which are man-made but have, over time, achieved characteristics of natural rivers). With regard to landscape ecology, the urban river landscape is an important physical element and a kind of ecological corridor in urban landscapes. River corridors play important ecological roles such as providing habitats, acting as filters and barriers, and being water sources and water sink etc. [1]. They also supply water resources and transportation ways, increase urban landscape diversity, enrich the life of urban citizens and contribute to stability, comfort, and sustainability in urban development $[2,3]$. Due to heavy disturbances throughout the urbanization process, urban rivers have become one of the most intensively influenced areas in the interaction between humans and natural processes. Human activities have vastly altered the structure and the function of urban river landscapes. This has occurred through the accelerated conversion of forestland and wetland to agricultural or urban land, the straightening of the meanderings of rivers, channel maintenance, and industrial development. Industrial development has caused water pollution, erosion, sedimentation and downstream flooding. Human activities have resulted in the decrease of naturalness, diversity, feasibility and beauty of the urban river landscapes.

Landscape ecology is a comprehensive discipline which emphasizes the research of landscape structures and functions, dynamic changes of landscapes, mutual functional mechanisms, optimized patterns, and the reasonable development or protection of landscapes [4-7,8]. Because of the complex interaction between the inner and outer elements of river landscapes, various data from different sources have to be integrated, such as geographical data, ecological data, social and economic data etc. Data acquiring and processing technologies such as remote sensing, geography information system, simulation models should also be integrated [3,9]. In addition, the protection and the development of urban rivers are closely connected with economic and social interests; a single discipline such as ecology cannot differentiate natural influences from man-made influences in the change of urban rivers [10]. However, landscape ecology, being inter- and multi-disciplinary, can integrate the different study fields of ecology, geography, economics and humanities, among others, in order to describe and resolve complex scientific and social problems and supply scientific support for the planning and management of urban rivers. What's more, landscape ecology emphasizes not only the temporal and spatial change that landscapes undergo but also the relationship between spatial patterns and ecological processes [1]. Urban rivers are multi-functional corridors within urban landscapes. Both their structural characteristics of width, connectivity, curvature and their functional characteristics of source, disturbance extent and intensity are connected with each other and together play great roles in the development of urban rivers and even of the whole city. In brief, landscape ecology adapts to quantitatively describe and evaluate urban river landscapes.

Therefore, by employing landscape ecology principles to analyze the structure, function, context, fragmentation, temporal changes and interconnection with other urban landscape elements, we could grasp the general and synthetically knowledge of urban river landscapes which will support the management and sustainable development of urban river landscapes.

The primary objective of this study was to apply landscape ecological knowledge to analyze the urban rivers. Based on the literature review of relevant research in river corridors, we will use the fundamental

*Corresponding author: Jun Yue, Shenzhen Urban Planning and Land Resource Research Center, 518034, P.R. China, E-mail: yuejunsz@hotmail.com

Received December 04, 2011; Accepted January 04, 2012; Published January 12, 2012

Citation: Yue J (2012) Urban Rivers: A Landscape Ecological Perspective. Hydro Current Res 3:125. doi:10.4172/2157-7587.1000125

Copyright: (c) 2012 Ede S, et al. This is an open-access article distributed under the terms of the Creative Commons Attribution License, which permits unrestricted use, distribution, and reproduction in any medium, provided the original author and source are credited. 
concepts of landscape ecology including patter, function, change, scale and disturbance to analyze urban river landscapes. In every key issue, we probe into the relative studying emphases and some problems to resolve.

\section{Background}

In landscape ecology, river corridors include rivers and vegetation zones distributed along the river that are different from the immediate surroundings $[1,11]$. So the researches on urban river corridors are concentrated on three main aspects, water body, riparian vegetation, and river landscape planning.

Because urban rivers have been widely affected by the forces of urbanization, much research have probed into environmental water capacity, changes in water quantity and quality, and development of water resources from the perspective of preventing environmental water pollution [12-14]. Some researchers have emphasized the methods and approaches of urban rivers ecological construction extensively in the natural ecological riverway construction $[15,16]$. Based on the context of urban landscapes, some researchers have studied the relationship between river corridors and man-made corridors about the benefitdistance effect; and have compared similarities and differences in structure and function of these two kinds of corridors [3,17-19]. Furthermore, some researchers have discussed how the change of other urban landscape components (especially land use and land cover change) affects the river landscapes. Studies in this field are going deeper and deeper from the early exam field research $[20,21]$ to the present application of different watershed hydrological models [2227]. These models could make it possible to generally estimate the hydrological effects of river landscapes at many different scales.

Along with increasing concern for urban greenways and green spaces, much research has emphasized the planning, utilization and protection of riparian vegetation. These studies mainly include these analyses as follows: (1) the dynamic change of riparian vegetation characterized by some landscape indices such as dominance, richness, etc. $[28,29] ;$ (2) the results of human activities that influence the riparian change [30,31]; (3) the analyses of interaction relationship among riparian vegetation, land use, water body and ecological elements etc. $[32,33]$; (4) the studies on the limitation and special demands in mapping the riverine landscapes [34-38]; (5) some studies on determining the optimal width and the validity of riparian vegetation buffer zones [39,40,36,41].

Many landscape planners are concerned with the design of the urban riparian area-a primary space showing the inter-development between the natural and the man-made landscape [42]. They investigate the safety, naturalness, close to water and other characteristics of river corridors and its surroundings and cater to the ecological function of urban rivers, architectural aesthetics, human-oriented development $[43,44]$. Then they plan the whole urban river area including the river water itself, riparian area and surrounding area and table a proposal of implementing framework for river corridors and riparian vegetation $[3,45,46]$. In other words, they attempt to build the riparian landscape belt with urban characteristics in an appropriate way.

From the literature review showed above, we can find that whatever the study concentrate on what kind of characteristic of urban rivers, it is always undeviating from the analysis and evaluation of river condition. The condition of urban river landscapes could reflect the results from generally analyzing and evaluating the river characteristics. So the description of river condition should include the spatial structure and distributing characteristic, service function, temporal and spatial change of urban river landscapes and the interaction between river change and climate or land use change. The collection and analysis of various information all need to initiate multi-scale and multi-discipline research on urban river landscapes. The theory of landscape ecology will supply a total-process method for urban river study and finally afford the solving of complex scientific and social problems in urban water resources.

\section{Analysis of Urban Rive Landscapes}

Landscape structure, function and dynamic change are the foundation of research in landscape ecology $[1,47,48]$. In the analysis of urban river landscapes, these topic concepts (pattern, process and function) are also the major contents. The framework of this study is showed in Figure 1.

\section{Pattern}

To analyze the pattern of the urban river landscapes, we should carry out research on urban river corridor as well as urban river network.

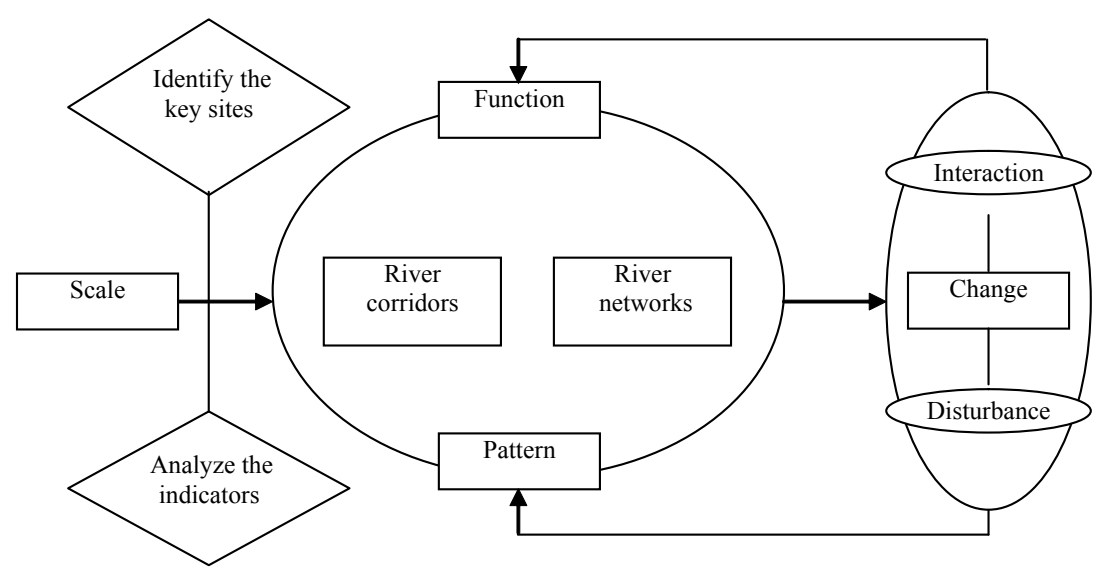

Figure 1: The framework of urban river landscape analysis. 
In the analysis of river corridors, it is necessary to analyze spatial characteristics including width, curvature, ratio of width and length, break number, etc., and internal characteristics about variability gradient at species richness, width effect, elevation difference and depth change and so on. Consequently, the width effect plays a controlling role along the river corridor $[1,8]$.

Furthermore, different urban river corridors connect to each other and form river networks, so hierarchical relativity has been the typical characteristic of urban river networks. Because of the connectivity between different urban river corridors, we should research urban river networks simultaneously. We can take the associated river corridors at the urban or regional scale as a hierarchical network in order to research its structure, function and dynamic change especially between different river corridors. There are many metrics to analyze this characteristic, such as connectivity, circuitry, node number, mesh size, density etc. In addition, we should consider vegetation rate, building density, and the commercial business density around urban river networks to describe the adjacent conditions. Based on this quantitative analysis, we will acquire the temporal and spatial information of urban rivers. This information will help us understand and describe the dynamic change of urban rivers.

\section{Function}

Forman and Godron [1] pinpointed the four main ecological functions of corridors about habitat, conduit, barrier or filter, and source. Urban rivers not only supply the ecological functions mentioned above, but also supply the functions including the economic function, safe function and aesthetics function and so on. Whether the realization of ecological functions or the realization of other economic, social and cultural functions all depend on the analysis of water quantity and water quality these two elements. Different combination of water quantity and water quality with different spatial and temporal characteristics would make it possible for diversity of river functions. So the water quantity and water quality are the two main contents in the study of landscape function of urban rivers.

On the one hand, it is necessary to collect hydro-meteorological data about urban hydrological circle and then to calculate and simulate the water quantity by hydrological models. On the other hand, in the analysis of water quality, we should investigate the monitoring data from environmental protection bureau or environmental monitoring station and distinguish polluted water quality from natural water quality. This will do good to understand the reason of water pollution.

On the basis of the analysis of water quantity and water quality, we can evaluate the different functions of urban river landscapes such as water supply, wastewater discharge, flood control, tourism and recreation, life support etc. Among these functions, we especially concentrate on evaluating the ecological functions of urban river landscapes including biomass, water preservation ability, groundwater refresh rate, self-purification ability, riparian habitats function, recreational value etc. [49]. These ecological functions could be well used to explain the natural characteristics of urban river landscapes.

\section{Change}

The investigation of landscape changes is a main pillar of landscape ecology. The structure determines the function, and changes in function may be reflected again in change of the structure $[1,5,47]$. So it is necessary to study the dynamic change of patterns and functions of urban rivers at different temporal and spatial scales. We need not only analyze urban rivers at different temporal scales within same spatial scale but also compare changes at different spatial scales within the same temporal scale. On the basis of the combination of these two analyses, we could determine the change characteristic of urban rivers.

In order to research the pattern change of urban rivers, we normally describe urban river corridors using four dimensions. Research can follow from upstream to downstream, from the central river to the riparian upland, from the river surface to the riverbed and analyze how these three spatial patterns change with time.

However, usually only symptoms of landscape change are described; it is hard to grasp the underlying causes of landscape changes, especially with regard to functional aspects and relations [50]. As a result, we should evaluate the change of landscape functions by combining the ecological function, stability, and available utilization etc. Through the analysis of these changes of functions, we can find the critical changes and disturbance reasons, which will supply valid information for prohibiting or reversing deleterious trends and for designing appropriate approaches to urban river landscape construction.

There are extensive interconnection and interaction between different kinds of urban landscapes. For example, riparian land use will be limited by the hydrological characteristics and ecological processes of river; whereas river corridors will be influenced by the riparian land use. Accordingly, we need to know the change of relationship and interaction between river landscapes and other urban landscape elements. With the context of urban landscape connectivity, we can work out the reasonable development programs of concrete river landscapes.

\section{Scale}

Scale is a key issue in urban river landscape planning. Changes in spatial extent may alter the analysis of landscape pattern [5]. Thus, an appropriate scale and method must be chosen before urban river landscape planning can proceed further. For the continuous multi-scale correlation of river system with different orders, we should analyze the urban river landscapes at the larger and smaller scale than the urban regional scale. According to differences in the relative width of urban river landscapes, the space scale can be divided into small, medium and large scales. The analysis of urban river landscapes at the small scale mainly is the design and planning of river landscape environment including river ways, river and riparian vegetation. Current urban river landscape environmental planning always considers the multi-functional nature of urban rivers and tries to enhance safety, economization, ecology, aesthetics, accessibility of people to the river and cultural aspects. Research of urban river landscapes at the medium scale includes landscape patterns and ecological effects of urban rivers on the urban area or certain region. At this level, all the rivers in urban region can be seen as a whole entity. Associated studies mainly cover the planning, modification or construction of urban river landscapes. Research at the large scale usually analyzes interactions between land use/land cover change, soil and water loss, deterioration of water quality and other problems in catchment areas from the viewpoint of heterogeneity, integrity and equilibrium of the whole watershed. Although different research at different scales concern different scholarly areas and methods, these researches do relate closely to each other. 


\section{Disturbance}

As a type of landscape influenced by man-made disturbance, urban rivers have already changed dramatically in both form and hydrological characteristics. There is a need to understand the fundamental mechanisms between human induced disturbance and the inherent variability of urban rivers in order to protect and develop urban river landscapes sustainably.

Urban river disturbance analysis is a quantitative method that is also a good foundation for landscape planning and structure optimization. This analysis can have many uses [51]: (1) indicate degree of naturalness of urban rivers by the classifying it by degree of disturbance; (2) detect the headstream, extent of degradation, and other key aspects; (3) distinguish orders of priority to aid in restoring and reconstructing urban rivers; (4) investigate the aquatic environment, riparian vegetation and estuarine organisms; (5) improve the understanding of what actions are most influential upon river landscapes and the manner in which they do so. Degree of disturbance results is closely related to the choice of indicators. We should study the different values of indicators and develop a proper disturbance evaluation system. Certainly, we should combine degree of disturbance analysis with a specific area to choose the appropriate indicators and analyze the weighted values in detail.

\section{Discussion}

From these key topics (pattern, function, dynamic change, scale and disturbance) discussed above, we can find that the important issue in describing the river condition is the analysis and explanation of the indices being chosen.

A set of appropriate indicators could describe fast change, sensitive, specific, reliable, and inexpensive characterization of river conditions. Indicators are simple measures that represent key components of the system and have meaning beyond the attributes that are directly measured [52]. So a very large number of studies pay much attention to the choice and application of indicators. For example, the United States Environmental Protection Agency (USEPA) has proposed indicators that include landscape ecological metrics, land cover metrics and hydrological metrics in order to analyze (i) water catchment integrity; (ii) landscape stability and resilience; (iii) biotic integrity and diversity [53]. Many researchers have highlighted the need for procedures that measure a range of vegetation, soil, hydrology, climate and ecosystem condition to describe the temporal and spatial change of river landscapes, thereby providing the basis for more effective and sustainable river management strategies [52,54-58]. The results of these studies have showed that sustainable development of river landscapes must integrate physical, chemical and ecological indicators of rivers for getting the general condition and the key ecological function such as stability, resilience and sensitivity and so on $[57,59]$.

What's more, there are some certain key sites with critical threshold effects on the ecological process of species dispersal and maintenance [60]. These key sites include intersection of two or more rivers, the position of urban rivers input or output reservoir, outfall location of point source pollution on urban rivers, connecting point of urban rivers and other transportation corridors, and headstream of degradation and discontinuous ecological segments in urban rivers and so on. For the specific pattern and the complex function of these sites, its dynamic change certainly showed diversity. Hence we should carefully study on it.

\section{Conclusion}

Urban rivers have a prime role in urban ecological construction and sustainable development. The present trends of urban river landscape research indicate that urban rivers, the precious natural continuum, need to be studied in accordance with landscape ecology theory. Theories of landscape ecology integrating ecological, physical, economic and man-made factors will be applied to describe patterns, processes, and functions of urban rivers. At the same time, because landscape ecology theory is adapted to analyze spatial structures and ecological process of the urban rivers, this research is also important in the application of landscape ecology.

The physical characteristics of urban rivers are the basis of exerting ecological functions. We should coordinate the relationship between urban development and river utilization, and combine urban river landscape ecological construction with the other ecological constructions. Because of extensive interaction between different elements in urban landscapes, for example, the land uses of riparian zones will influence hydrological processes of urban rivers and simultaneously urban rivers will limit the development of riparian land, so it is necessary for the concrete urban river landscape ecological construction to analyze the interaction between urban river landscapes and the other elements in urban landscapes and to acquire the appropriate development program for urban river landscape construction.

Because urban rivers are deeply influenced by the interaction of human activities and natural processes, the understanding of disturbance degree is fundamental to the proper planning and design of urban river landscapes. Furthermore, as a component in urban landscapes, urban rivers have a close relationship with the other elements. Its structure, function and dynamic change are dependent on analysis of the interrelationships. For the complexity of interaction, we should do much more work on scale effects, choice of indicators, heterogeneity, connectivity, landscape value diversity etc. to provide more information for urban river landscape ecological construction and to build a framework for the sustainable development of urban river networks.

\section{Acknowledgements}

The authors gratefully acknowledge to Michael Gallagher for his suggestions for revising the manuscript.

\section{References}

1. Forman RTT, Godron M (1986) Landscape Ecology. John Wiley, New York.

2. Cook EA (1991) Urban landscape networks: an ecological planning framework. Landscape Res 16: 7-15.

3. Baschak LA, Brown RD (1995) An ecological framework for the planning design and management of urban river greenways. Landsc Urban Plan 33 211-225.

4. Risser PG, Karr JR, Forman RTT (1984) Landscape ecology: Directions and approaches. A workshop held at Allerton Park, Piatt: County Illinois 16.

5. Turner MG (1989) Landscape ecology: the effect of pattern on process. Annu Rev Ecol Syst 20: 171-197.

6. Pickett STA, Cadenasso ML (1995) Landscape ecology: Spatial heterogeneity in ecological systems. Science 269: 331-334. 
7. Wu JG, Hobbs R (2002) Key Issues and Research Priorities in Landscape Ecology: An Idiosyncratic Synthesis. Landsc Ecol 17: 355-365.

8. Fu BJ, Chen LD, Ma KM, Wang YL (2001) Principles and Applications of Landscape Ecology. Beijing: Science Press (In Chinese).

9. Freeman RE, Ray RO (2001) Landscape ecology practice by small scale river conservation groups. Landsc Urban Plan 56: 171-184.

10. Zavala MA, Burkey TV (1997) Application of ecological models to landscape planning: the case of the Mediterranean basin. Landsc Urban Plan 38: 213-227.

11. Xiao DN, Li XZ, Gao J, Chang Y, Li TS (2003) Landscape Ecology. Beijing, Science Press.

12. Niemczynowicz J (1999) Urban hydrology and water management- present and future challenges. Urban Water 1: 1-14.

13. Interlandi SJ, Crockett CS (2003) Recent water quality trends in the schuylkill river, pennsylvania, usa: a preliminary assessment of the relative influences of climate, river discharge and suburban development. Water Research 37: 1737-1748.

14. Ye L, Li D, Tang T, Qu X, Cai Q (2003) Spatial distribution of water quality in the xiangxi river, china. Chinese Journal of Applied Ecology 14: 1959-1962.

15. Yan SY, Wang XR (1999) Preliminary study on the roles and applied ways of urban rivers in urban ecological construction. Urban Environment \& Urban Ecology 12: 36-38.

16. Xia JH, Yan ZM (2004) Advances in research of ecological riparian zones and its trend of development. Journal of Hohai University (Natural Sciences) 32: 252-255

17. Ryan RL (1998) Local perceptions and values for a midwestern river corridor. Landsc Urban Plan 42: 225-237.

18. Zong YG (1999) The Corridor Effects in Urban Ecological Landscape Planning-A Case study on Beijing. Acta Ecologica Sinica 19: 145-150.

19. Che SQ (2001) Study on the Green Corridors in Urbanized Areas. Urban Ecological Study 25: 44-48.

20. Langford KJ (1976) Change in yield of water following a bush fire in a forest of Eucalyptus regnans. J Hydrol 29: 87-114.

21. Bosch JM, Hewlett JD (1982) A review of catchment experiments to determine the effect of vegetation changes on water yield and evapotranspiration. $J$ Hydrol 55: 3-23.

22. Krysanova V, Muller-Wohlfeil DI, Becker A (1998) Development and test of a spatially distributed hydrological/water quality model for mesoscale watersheds. Ecol Modell 106: 261-289.

23. Brun SE, Band LE (2000) Simulation runoff behavior in an urbanizing watershed. Comput Environ Urban Syst 24: 5-22.

24. Fohrer N, Haverkamp S, Eckhardt K, Frede HG (2001) Hydrologic response to land use changes on the catchment scale. Phys Chem Earth (B) 26: 577-582.

25. Tong STY, Chen WL (2002) Modeling the relationship between land use and surface water quality. J Environ Manage 66: 377-393.

26. Eckhardt K, Breuer L, Frede HG (2003) Parameter uncertainty and the significance of simulated land use change effects. J Hydrol 273: 164-176.

27. Hundecha Y, Bardossy A (2004) Modeling of the effect of land use changes on the runoff generation of a river basin through parameter regionalization of a watershed model. J Hydrol 292: 281-295.

28. Maekawa M, Nakagoshi N (1997) Riparian landscape changes over a period of 46 years, on the Azusa River in Central Japan. Landsc Urban Plan 37: 37-43.

29. Qi J, Marsett RC, Moran MS, Goodrich DC, Heilman P, et al. (2000) Spatial and temporal dynamics of vegetation in the San Pedro River basin area. Agricultural and Forest Meteorology 105: 55-68.

30. Inoue M, Nakagoshi N (2001) The effects of human impact on spatial structure of the riparian vegetation along the Ashida River, Japan. Landsc Urban Plan 53: 111-121.

31. Moffatt SE, McLachlan SM (2004) Understorey indicators of disturbance for riparian forests along an urban-rural gradient in Manitoba. Ecol Indic 4: 1-16.

32. Johnson WC, Dixon MD, Simons R, Jenson S, Larson K (1995) Mapping the response of riparian vegetation to possible flow reductions in the Snake River Idaho. Geomorphology 13: 159-173.

33. Miller JR, Schulz TT, Hobbs NT, Wilson KR, Schrupp DL, et al. (1995) Changes in the landscape structure of a southeastern Wyoming riparian zone following shifts in stream dynamics. Biological Conservation 72: 371-379.

34. Muller E (1997) Mapping riparian vegetation along rivers: old concepts and new methods. Aquatic Botany 58: 411-437.

35. Narumalani S, Zhou Y, Jensen JR (1997) Application of remote sensing and geographic information systems to the delineation and analysis of riparian buffer zones. Aquatic Botany 58: 393-409.

36. Apan AA, Raine SR, Paterson MS (2002) Mapping and analysis of changes in the riparian landscape structure of the Lockyer Valley catchment, Queensland Australia. Landsc Urban Plan 59: 43-57.

37. Congalton RG, Birch K, Jones R, Schriever J (2002) Evaluation remotely sensed techniques for mapping riparian vegetation. Computers and Electronics in Agriculture 37: 113-126.

38. Gutierrez M, Johnson E, Mickus K (2004) Watershed assessment along a segment of the Rio Conchos in Northern Mexico using satellite images. J Arid Environ 56: 395-412

39. Xiang WN (1993) Application of a GIS-based stream buffer generation mode to environmental policy evaluation. Environmental Management 17: 817-827.

40. Xiang WN (1996) GIS-based riparian buffer analysis: injecting geographic information into landscape planning. Landsc Urban Plan 34: 1-10.

41. Sparovek G, Ranieri SBL, Gassner A, Maria ICD, Schnug E, et al. (2002) A Conceptual Framework for the Definition of the Optimal Width of Riparian Forests. Agriculture, Ecosystems and Environment 90: 169-175.

42. Forman RTT (1995) Land Mosaics: The Ecology of Landscapes and Regions. Cambridge University Press, Cambridge.

43. Gobster PH, Westphal LM (2004) The human dimensions of urban greenways: planning for recreation and related experiences. Landsc Urban Plan 68: 147 165

44. Yu KJ, Zhang L, Liu YJ (2004) The Multifunctional Approach toward Waterfront Landscape Design-With a Case Study of Cixi in Zhejiang Province. Journal of Chinese Landscape Architecture 5: 28-32.

45. Qureshi ME, Harrison SR (2001) A decision support process to compare riparian revegetation options in the scheu creek catchment in north queensland. J Environ Manage 62: 101-112.

46. Asakawa S, Yoshida K, Yabe K (2004) Perceptions of urban stream corridors within the greenway system of Sapporo, Japan. Landsc Urban Plan 68: 167 182.

47. Forman RTT (1995) Some general principles of landscape and regiona ecology. Landsc Ecol 10: 133-142.

48. Turner MG (1990) Spatial and temporal analysis of landscape patterns. Landscape Ecology 4: 21-30.

49. Sarapatka B, Sterba O (1998) Optimization of agriculture in relation to the multifunctional role of the landscape. Landsc Urban Plan 41: 145-148.

50. Bastian O, Roder M (1998) Assessment of landscape change by land evaluation of past and present situation. Landsc Urban Plan 41: 171-182.

51. Stein JL, Stein JA, Nix HA (2002) Spatial analysis of anthropogenic river disturbances at regional and continental scales: identifying the wild rivers of australia. Landsc Urban Plan 60: 1-25.

52. Aspinall R, Pearson D (2000) Integrated geographical assessment of environmental condition in water catchments: linking landscape ecology, environmental modeling and gis. J Environ Manage 59: 299-319.

53. Environmental Protection Agency (EPA) (1994) Landscape Monitoring and Assessment Research Plan. US EPA 620/R-94/009.

54. Jolly I, Caitcheon G, Donnelly T, Hafner S (1996) Physical and chemical 
indicators of water quality. In: Walker J, Reuter DJ (Eds.), Indicators of Catchment Health: A Technical Perspective. CSIRO, Melbourne 131-141.

55. Ladson AR, White LJ, Doolan J, Finlayson BL, Hart BT, et al. (1999) Development and testing of an index of stream condition for waterway management in Australia. Freshwater Biol 41: 453-468.

56. Maddock I (1999) The importance of physical habitat assessment for evaluating river health. Freshwater Biol 41: 373-391.

57. He CS, Malcolm SB, Dahlberg KA, Fu B (2000) A Conceptual framework for integrating hydrological and biological indicators into watershed management. Landsc Urban Plan 49: 25-34.

58. Doyle MW, Harbor JM, Rich CF, Spacie A (2000) Examining the effects of urbanization on streams using indicators of geomorphic stability. Phys Geogr 21: 155-181.

59. Fryirs K (2003) Guiding Principles for Assessing Geomorphic River Conditions:
Application of a Framework in the Bega Catchment, South Coast, New South Wales, Australia. Catena 53: 17-52.

60. Yu KJ (1996) Security Patterns and surface models in landscape ecologica planning. Landsc Urban Plan 36: 1-17.

61. Leitao AB, Ahern J (2002) Applying landscape ecological concepts and metrics in sustainable landscape planning. Landsc Urban Plan 59: 65-93.

62. Naveh Z, Lieberman AS (1984) Landscape Ecology: Theory and Application Student Edition 1990 Springer, New York.

63. Wang $X$ (2001) Integrating water-quality management and land-use planning in a watershed context. J Environ Manage 61: 25-36.

64. Wang X, Yu S, Huang GH (2004) Land allocation based on integrated gisoptimization modeling at the watershed level. Landsc Urban Plan 66: 61-74.

65. Wei NX (1996) GIS-based riparian buffer analysis: injecting geographic information into landscape planning. Landsc Urban Plan 34: 1-10. 